症例報告

\title{
プロテイン $\mathrm{S}$ 欠乏症による上腸間膜静脈血栓症の 1 例
}

\author{
千葉県立佐原病院外科, 摂津医誠会病院外科*
}

矢 野 佳子平 位 洋 文*

\begin{abstract}
症例は 39 歳の男性で, 下血と腹痛を主訴に来院し急性腸炎の診断で入院した. 入院時白血球 数 $13,100 / \mathrm{mm}^{3}$ と上昇していたが，その他血液検査ならびに腹部 CT では特に異常を認めな かった，数日間の絶食補液にて症状はいったん軽快するも，再度下血，腹痛ならびに腹膜刺激 症状が出現した. 第 11 病日の造影 CT で腹水と小腸壁の著明な肥厚, 上腸間膜静脈血栓を認め, 開腹手術を施行した．開腹時血性腹水大量, 空腸約 $35 \mathrm{~cm}$, 回腸約 $25 \mathrm{~cm}$ が壊死に陥り, 回腸で 穿孔を認めた．回腸，空腸部分切除術を施行した。病理組織検査にて腸間膜静脈内に新鮮およ び陳旧性血栓が多発し，腸管壁の全層性出血性壊死を認めた。血液凝固検査でプロテイン S 抗原が $24.2 \%$, 活性值 $11 \%$ と低值を示し，プロテイン $\mathrm{S}$ 欠乏症が本症例の原因と考えられた. プロテイン S 欠乏症に起因する腸間膜静脈血栓症は非常にまれであり，文献的考察を加えて報 告した.
\end{abstract}

\section{はじめに}

腸間膜静脈血栓症（以下，MVT）は比較的まれ な疾患で早期診断, 治療が困難であるとされてい る.また, Protein S (以下, PS) 欠乏症は常染色 体優性遺伝病で静脈系の血栓症を契機に発見され ることが多い. 今回, 我々は先天性 PS 欠乏症が原 因と考えられた上腸間膜静脈血栓症（SMVT）の 1 例を経験したので報告する.

\section{症例}

患者 : 39 歳, 男性

主訴 : 下血, 腹痛

家族歴：特記すべきなし.

既往歴：15 年前十二指腸潰瘍.

現病歴：2004 年 6 月上旬下腹部痛出現. 1 週間 後腹痛増強, 嘔吐, 下血を来し, 当院内科を受診 し，急性腸炎の診断で入院となった。

入院時検查所見 : 入院時, 白血球 $13,100 / \mathrm{mm}^{3}$ と上昇. また, $\mathrm{LDH}$ が 480IU/ $l$ とやや増加を認め たが, CRP も陰性でその他著変を認めず. 腹部単 純 X 線にて free air は認めなかった.

$<2006$ 年 3 月 22 日受理 $>$ 別刷請求先 : 矢野 佳子 T287-0003 佐原市佐原イ 2285 千葉県立佐原病院 外科
腹部 CT 所見：入院時の腹部 CT では腹腔内 free air を認めず, 特異的な所見は認めなかった. 絶食および補液にて保存的に加療し，第 6 病日に は腹痛の軽快ならびに白血球数の改善を認め摂食 を開始するが, その後腹痛, 嘔吐が再出現した.

第 11 病日には白血球 $24,400 / \mathrm{mm}^{3}$, CRP $14.8 \mathrm{mg}$ / $\mathrm{dl}$ に上昇し, 腹膜刺激症状も出現したため造影 CT を施行するに, 小腸壁肥厚 (Fig. 1a), 腹水, 上腸間膜静脈内に透亮像を認め(Fig. 1b), 上腸間 膜静脈血栓症ならびに小腸壊死の診断にて開腹手 術を行った。

手術所見：開腹時，血性腹水を大量に認めた. 回盲部より $40 \mathrm{~cm}$ 口側の回腸が壊死に陥り穿孔を 認めた.また, Treitzより約 $60 \mathrm{~cm}$ 肛門側空腸も壊 死に陥っていた．回腸を約 $25 \mathrm{~cm}$, 空腸を約 $35 \mathrm{~cm}$ 切除した.

切除標本検查所見 : 切除回腸, 空腸腸管内腔は 黒色血液で充満し, 腸管壁肥厚と粘膜下出血, 壊 死を認めた（Fig. 2). 回腸壁は壊死部で穿孔して いた（Fig. 2b).

病理組織学的検査所見 : 全層性の壊死ならびに 肉芽形成を認めた (Fig. 3a)．腸間膜静脈内腔には 多数の血栓形成を認め (Fig. 3b), 静脈血栓の中に 
Fig. 1

a : Abdominal CT scan showed thickened small bowels (arrow head).

b : Abdominal CT scan demonstrated thrombi (arrow) in the superior mesenteric vein with ascites.
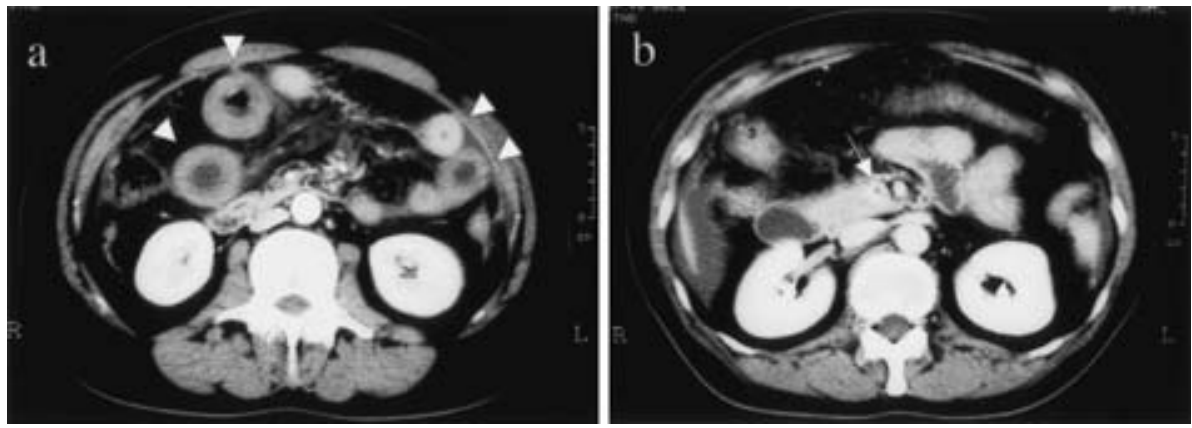

Fig. 2 Macroscopic findings of resected specimen. a : Resected jejunum showed congestive necrosis. b : Resected ileum showed marked transmural necrosis with perforation (arrow).
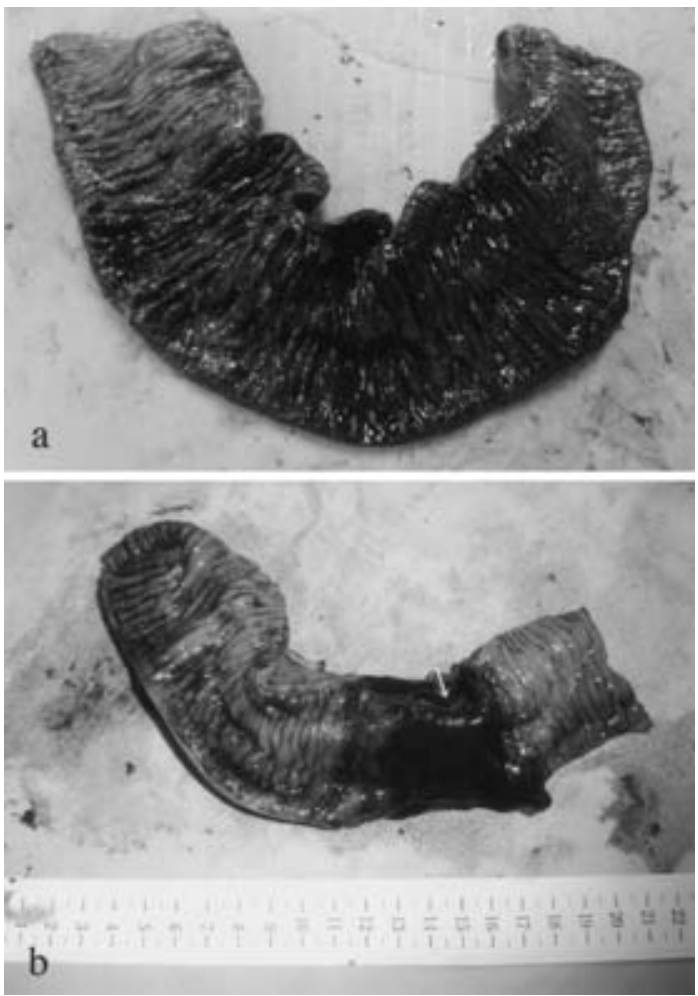

は完全に器質化され，内部に新生血管を形成し再 疎通するものも認めた（Fig. 3c）.

術後経過：術後凝固系検査を実施したところ，
PS 抗原量 24.2\%（正常 60～150\%），活性值 11\% （正常 60～150\%）と著明に低下しており（Table 1)，本症例の原因と考えられた。このためワー ファリン経口投与を開始した。術直後 D-dimer が $5.1 \mu \mathrm{g} / \mathrm{ml}$, TATも $6.9 \mathrm{ng} / \mathrm{ml}$ と高值であった が, 術後 44 日目 D-dimer, TATともに正常值と なり退院した。退院後外来にてワーファリンでコ ントロール中であるが, 術後 1 年半を経た現在 Ddimer も正常で再発徴候を認めない.

\section{考察}

MVT は腸管のうつ血性梗塞を来す比較的まれ な疾患で 1913 年 Eliot $^{1)} に よ り$ 初めて報告され, そ の発生頻度は腸間膜血管閉塞性疾患の 5〜15\%を 占めると報告されている2).

MVT は発症時特徵的な症状がないこと, なら びに潜在性に病気が進行することよりいまだに早 期診断は困難である。腸間膜動脈閉塞症が急激な 腹痛で発症し，小腸壊死を起こし腹膜炎症状を呈 するのに対して，MVTの発症は潜行性でその進 行は緩徐である。血栓形成が緩徐な場合しばしば 側副血行が生じたり，血栓内の再疎通（recanalization)が起こることにより代償され, すぐに小腸 壊死に至らないことも多く，時に 3 週間も曖昧な 症状が継続したとの報告もある ${ }^{3)}$. 本症例でも切除 標本の病理学的検査で腸間膜静脈の器質化血栓の 再柾通所見を多数認めており, 病状の進行は比較 的緩慢で経過は長いことを示唆する.

診断するにあたり血液検査ではあまり特徴がな 
Fig. 3

a : The histopathologic examination showed marked transmural hemorrhagic necrosis of the small bowel $($ HE. $\times 40)$.

$\mathrm{b}$ : Microscopic findings revealed thrombi(arrow)in the superior mesenteric vein $(\mathrm{HE} . \times 100)$.

c : Organized thrombus with recanalization (arrow) was also observed (HE. $\times 100)$.
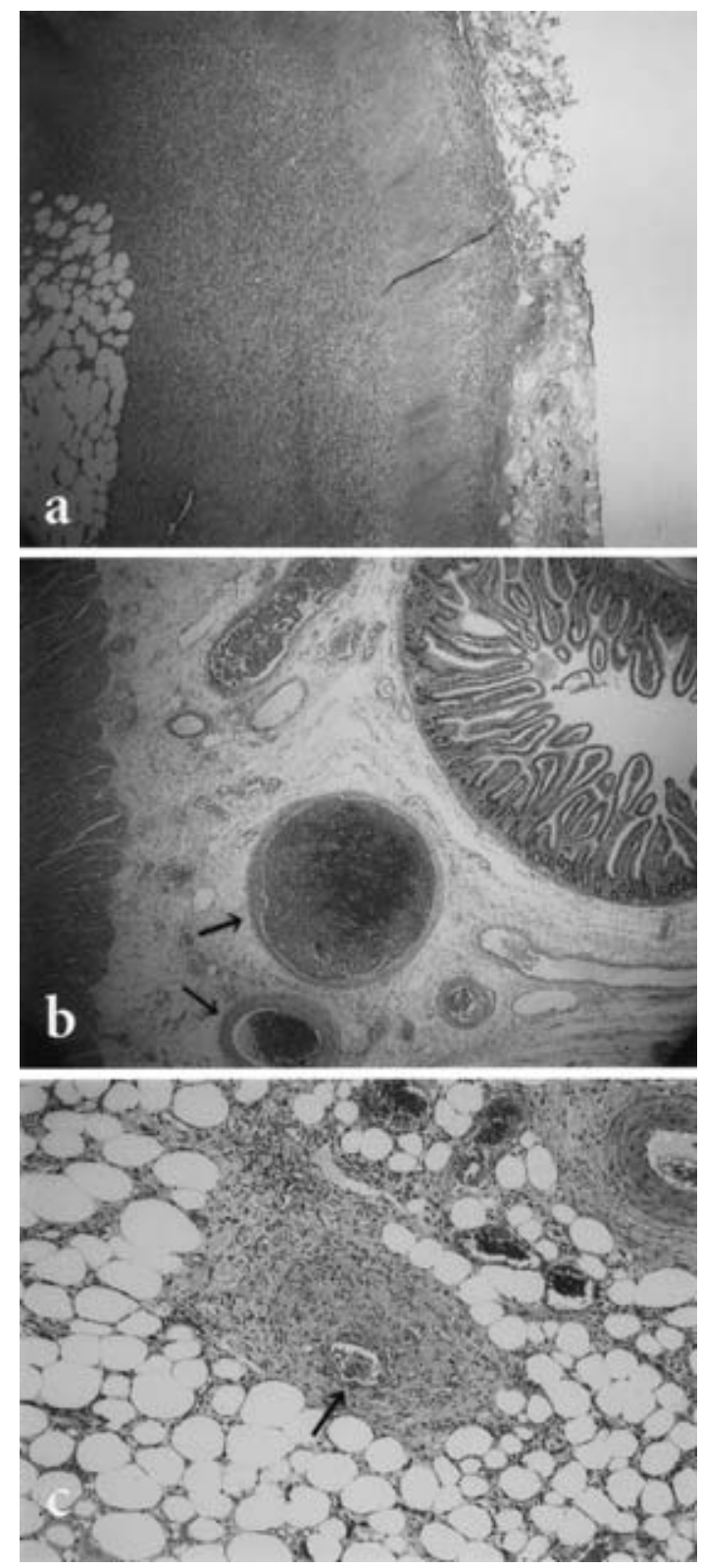

Table 1 Coagulation studies

\begin{tabular}{ll}
\hline PT & $81.7 \%(80 \sim 120 \%)$ \\
APTT & $27.8 \mathrm{sec}(26.0 \sim 38.0 \mathrm{sec})$ \\
D-dimer & $5.1 \mu \mathrm{g} / \mathrm{ml}(0 \sim 1.0 \mu \mathrm{g} / \mathrm{ml})$ \\
TAT complex & $6.9 \mathrm{ng} / \mathrm{ml}(1.0 \sim 4.1 \mathrm{ng} / \mathrm{ml})$ \\
AT-III & $98 \%(75 \sim 125 \%)$ \\
Plasminogen & $10.3 \mathrm{mg} / \mathrm{dl}(9.1 \sim 14.5 \mathrm{mg} / \mathrm{dl})$ \\
Protein C activity & $107 \%(70 \sim 140 \%)$ \\
Protein S antigen & $24.2 \%(60 \sim 150 \%)$ \\
Protein S activity & $11 \%(60 \sim 150 \%)$ \\
Loops anticoagulant & $1.1(0 \sim 1.3$ ratio $)$ \\
\hline
\end{tabular}

いことが多く, 白血球上昇と LDH (lactic dehydrogenase)の上昇を認めるのみとの報告が多い4). 血 管造影検査は有用であるが，門脈圧立進時の血栓 形成と異なり，凝固立進にもとづく血栓は，末梢 の小血管より生じて成長し, 中枢に拡大すること が多く ${ }^{5)}$, 腸間膜静脈の本幹でなく末梢分枝のみ血 栓を形成している場合 false negative となること がある ${ }^{6}$.このため, 血管造影検査による診断率は 全 MVTの 55\%にすぎなかったのに対し，CT では $90 \%$ 以上の症例で静脈血栓の存在が指摘可 能で診断に最も有用であったと報告されている7 . CT の特徵としては静脈内血栓の存在の他, 腹水 貯留, 小腸のうっ血にもとづく小腸壁の肥厚, 小 腸拡張像などがあげられており ${ }^{8}$, 本症例でもこれ らすべての特徴を認めた。

MVT の発症原因も多岐にわたり真性多血症, 血小板増加症などの骨髄増殖性疾患や AT-III, Protein C (PC), PS，プラスミノーゲン欠そ症な ど先天性凝固異常に起因するもの, 妊娠, 肝硬変, ネフローゼ症候群や経口避妊薬による後天性凝固 異常やその他門脈立進症や腹腔内炎症, 食道静脈 瘤硬化療法後によるものなどに分類される，本症 例はPS 抗原量 $24.2 \%$, 活性值 $11 \%$ と著明に低下 し (Table 1), 患者に後天性の PS 欠乏症を示す疾 患の背景は認めず, 先天性 PS 欠乏症と診断した.

PS はビタミン K 依存性糖蛋白であり, 活性化 PC が凝固第 Va 因子や第 VIIIa 因子を不活化し て抗凝固作用を発揮する際, 補酵素として働く ${ }^{9}$. PS 欠乏症は常染色体優性遺伝性疾患で一般人口 での正確な頻度は不明であるが， 2 万人に 1 人と 推定されている ${ }^{10)}$. また, 静脈血栓症の患者に占め 
Table 2 Reported 25 cases of mesenteric vein thrombosis induced by PS deficiency

\begin{tabular}{|c|c|c|c|c|c|c|c|c|c|}
\hline No. & Author & Year & Age & Sex & $\begin{array}{l}\text { Site of venous } \\
\text { thrombus }\end{array}$ & $\begin{array}{c}\text { Prior thrombotic } \\
\text { episode }\end{array}$ & Treatment & $\begin{array}{c}\text { PS antigen } \\
(\%)\end{array}$ & $\begin{array}{c}\text { PS activity } \\
(\%)\end{array}$ \\
\hline 1 & Broekmans $^{9)}$ & 1987 & 30 & M & SMV & none & surgery & $0.45 *$ & - \\
\hline 2 & Vicente $^{12)}$ & 1987 & 23 & M & SMV, PV & DVT, PE & surgery & 41 & UD \\
\hline 3 & Vicente ${ }^{12)}$ & 1987 & 24 & M & SMV & leg ulcer & surgery & 31 & UD \\
\hline 4 & Fujiii13) & 1990 & 19 & M & SMV & leg ulcer & AC only & 18 & - \\
\hline 5 & Stefano ${ }^{14)}$ & 1990 & 29 & M & SMV & DVT & surgery, 2nd look ope & 45 & $<6$ \\
\hline 6 & Stefano ${ }^{14)}$ & 1990 & 65 & M & SMV & DVT, PE & surgery & 24 & $<6$ \\
\hline 7 & Clark $^{15)}$ & 1991 & 26 & M & SMV & none & surgery & 90 & 37 \\
\hline 8 & Inagaki ${ }^{16)}$ & 1993 & 25 & M & SMV & none & surgery, 2nd look ope & 63 & 10 \\
\hline 9 & Porter $^{17)}$ & 1993 & 22 & M & SMV & none & surgery & - & 17 \\
\hline 10 & Mien-chi Chen ${ }^{3)}$ & 1996 & 47 & M & SMV, PV & DVT & AC only & $0.40 * *$ & - \\
\hline 11 & Mien-chi Chen ${ }^{3)}$ & 1996 & 40 & M & SMV, PV, IMV & none & AC only & $0.39 * *$ & - \\
\hline 12 & $\operatorname{Kim}^{8)}$ & 1997 & 35 & M & SMV, PV & none & AC only & 43 & - \\
\hline 13 & Sugiura ${ }^{18)}$ & 1998 & 32 & M & $\mathrm{SMV}, \mathrm{PV}$ & none & surgery, 2nd look ope & 44 & $<10$ \\
\hline 14 & Yajima ${ }^{19)}$ & 1999 & 25 & M & $\mathrm{SMV}, \mathrm{PV}$ & none & AC then resection of stenosis & 58 & 22 \\
\hline 15 & $\mathrm{Lau}^{6)}$ & 1999 & 31 & $\mathrm{~F}$ & SMV & $\mathrm{PE}$ & surgery & - & $<30$ \\
\hline 16 & Ludwig20) & 1999 & 32 & M & SMV, PV, SV & none & AC only & 54 & - \\
\hline 17 & Draganov 21$)$ & 1999 & 47 & M & IMV & none & AC only & 127 & 49 \\
\hline 18 & Bonariol2) $^{2)}$ & 2000 & 41 & M & SMV, PV & DVT & surgery & 35 & - \\
\hline 19 & Tateishi22) & 2001 & 26 & M & SMV, PV, SV & none & AC then removal of adhesion & 151 & 48 \\
\hline 20 & Uemura $^{23)}$ & 2002 & 60 & M & SMV, PV & none & AC then resection of stenosis & 46 & $<10$ \\
\hline 21 & Ikeda $^{24)}$ & 2002 & 44 & M & IMV, SMV & none & surgery, 2nd look ope & 34 & - \\
\hline 22 & Kato $^{25)}$ & 2002 & 76 & $\mathrm{~F}$ & SMV & none & surgery & 74 & 19 \\
\hline 23 & Inoue $^{26)}$ & 2004 & 52 & M & SMV & DVT & AC then resection of stenosis & 33 & - \\
\hline 24 & Mori27) & 2005 & 54 & M & SMV & DVT, PE & surgery & 38 & - \\
\hline 25 & Our case & & 39 & M & SMV & none & surgery & 24 & 11 \\
\hline
\end{tabular}

る割合いは, ATIII 欠そ症が 12〜15\%, PC 欠そ症 が 5〜8\% に対して PS 欠乏症は少なく, 2〜 5\%を 占めるのみと報告されている ${ }^{11)}$. PS 欠乏による MVT は筆者が「PS」と「MVT」をキーワードと して 1983 年から 2005 年 10 月までの医学中央雑 誌と, 1989 年から 2005 年 10 月までの MEDLINE で検索し調べえた範囲では, 自験例も含めて 25 例(2)39112) 27)が原著として報告されているに過ぎず, 比較的まれである (Table 2)。これら 25 例の内訳 は年齢 19 歳から 76 歳, 平均 37.8 歳でMVT 全体 の発症平均年齢が 49.1 歳 7 であるとの報告より若 い.さらに, 今回 25 例中 10 例は MVT 発症以前に 下肢静脈血栓症や肺血栓症, 難治性皮膚潰瘍など の静脈血栓症の既往がある. Engesser ${ }^{28}$ の review においても, 先天性プロテイン S 欠乏症の人 が最初に血栓症を発症する平均年齢は 28 歳で, 35 歳までに $68 \%$ が血栓症を発症するとあり, 若年性
の発症を特徴とする。また, Engesser ら $^{28}$ の報告 では PS 欠乏症の男性は 42 人中 31 人が血栓症を 発症するのに対して PS 欠乏症の女性は 29 人中 8 人しか発症しなかったとある。 今回，我々の検索 した症例でも 2 例を除き残り 23 例すべてが男性 であり, PS 欠乏症の人が血栓症を実際発症するか どうかは性差が重要であることが示唆された。腸 間膜静脈血栓症の発症部位としては，主に上腸間 膜静脈や門脈であり，下腸間膜静脈血栓症は 3 例 とまれであった。

これらの症例において，プロテイン $\mathrm{S}$ の測定值 は抗原量が著明に低下しているものがほとんど で, 我々の症例も $24.2 \%$ と著明な低下を認めた. しかし，プロテイン S 抗原量は，補体系制御蛋白 C4b 結合蛋白に結合した生理的活性のない分画と 補酵素としての活性のある遊離型の総和であるた め，プロテイン $\mathrm{S}$ の総量である抗原量が低下せず 
に活性值のみ低下するプロテイン $\mathrm{S}$ 欠乏症も存

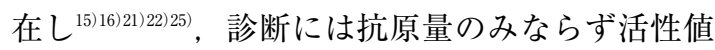
の測定が重要である.

治療法としては 1990 年の Chen $ら^{3)}, \operatorname{Kim} ら^{8)}$, 藤井ら ${ }^{13)}$, Draganov ${ }^{211}$ の症例では手術をせずに 抗凝固剤による保存的治療のみを行っている。 そ の他, 矢島ら ${ }^{19)}$, 上村 ${ }^{23)}$, 井上ら ${ }^{26)}$ の症例では比 較的早期に線溶, 抗凝固療法を開始しており, 腸 管壊死，穿孔性腹膜炎は回避できたが，後に虚血 による小腸狭窄のため小腸切除が施行された。 そ の他の症例のほとんどは, 腸管壊死, 穿孔性腹膜 炎にて緊急手術が施行され腸切除が行われてい る. 死亡率に関しては 1987 年 Wilson ら ${ }^{29)} 1988$ 年 Montany ${ }^{30}$ が MVT の 30 日以内の死亡率と して $50 \%$ と報告したが, 2001 年 Morasch ら ${ }^{7)}$ review では $23 \%$ まで減少し, 今回, 我々が調べた 25 例では入院後 30 日以内の死亡者は 1 例もな かった.このことは, CTなどを利用した早期診断 の向上ならびに抗凝固, 線溶療法を併用した治療 法によるところが大きいと考えられる。しかしな がら, Engesser ら ${ }^{28)}$ の報告では71 人の PS 欠乏症 において 39 人 $(55 \%)$ に静脈系の血栓症を認め, また血栓症の再発率も $77 \%$ と高いため退院後も 生涯ワーファリンの経口投与が必要であると考え られる。.今回, 調查したほとんどの施設でも長期 にわたる抗凝固剤投与が行われており，本症例で も術後ワーファリン投与を PT, D-dimerをモニ ターしながら投与を行っており, 術後 1 年半を経 過したが, 現在再発の徴候を認めない.

以上より，本疾患の治療にあたっては，早期よ り常にMVT の存在を視野にいれた検査を行い, 抗凝固線溶療法あるいは手術の治療選択を適切に 行う他, 原因疾患を特定し, 生涯適切な抗凝固療 法を行っていくことが再発の防止ならびに死亡率 の低下に重要であると考えられた。

なお, 本論文の要旨は第 60 回日本消化器外科学会定期 学術総会（2005 年 7 月, 東京) にて発表した.

\section{文献}

1) Eliot JW : The operative relief of gangrene of the intestine due to occlusion of the mesenteric vessels. Ann Surg 21:9-23, 1895
2) Bonariol L, Virgilio C, Tiso E et al : Spontaneous superior mesenteric vein thrombosis (SMVT) in primary protein $\mathrm{S}$ deficiency. A case report and review of the literature. Chirurgia italiana 52 : 183-190, 2000

3) Chen M, Brown MC, Willson RA et al : Mesenteric vein thrombosis : four cases and review of the literature. Dig Dis $14: 382$ - 389, 1996

4) Grieshop RJ, Dalsing MC, Cikrit DF et al : Acute mesenteric venous thrombosis-revisited in a time of diagnostic clarify. Am Surg 57 : 573-577, 1991

5) Abdu RA, Zakhour BJ, Dallis DJ : Mesenteric venous thrombosis 1971 to 1984 . Surgery 101 : 383-388, 1987

6) Lau LL, McMurray AH : Mesenteric venous thrombosis in Protein $\mathrm{S}$ deficiency : case report and literature review. Ulster Med J 68 : 33-35, 1995

7) Morasch MD, Evaugh JL, Pearce WH et al : Mesenteric venous thrombosis : a changing clinical entitiy. J Vasc Surg 34 : 680-684, 2001

8) Kim JY, Ha HK, Byun JY et al : Intestinal infarction secondary to mesenteric venous thrombosis : CT-pathologic correlation. J Comp Ass Tomogr $17: 382-385,1933$

9) Broekmans AW, Van Rooyen W, Westerveld BD et al : Mesenteric vein thrombosis as presenting manifestation of hereditary protein S deficiency. Gastroenterology 92 : 240-242, 1987

10) Bertina RM : Prevalence of hereditary thrombophilia and the identification of genetic risk factors. Fibrinolysis 2 : 7-13, 1988

11) Finazzi G, Barbui $T$ : Different incidence of venous thrombosis in patients with inherited deficiencies of antithrombin III, protein $\mathrm{C}$ and protein S. Thromb Haemost $71: 15-18,1994$

12) Vicente V, Alberca I, Tabernero MD : Ulcer necrotic legs as first manifestation of protein $\mathrm{S}$ deficiency. Blut $54: 253-254,1987$

13) 藤井 徹, 松井敏樹, 神谷吉宣ほか: プロテイン $\mathrm{S}$ 欠損症による上腸間膜静脈血栓症の 1 例. 綜合 臨 39:1857-1960, 1990

14) Stefano VD, Leone G, Teofili L et al : Mesenteric vein thrombosis in protein $\mathrm{S}$ congenital deficiency. Thromb Res 57 : 935-944, 1990

15) Clark DA, Willams WL, Marlar RA : Mesenteric vein thrombosis associated with a familial deficiency of free protein S. Arch Pathol Lab Med $115: 617-619,1991$

16) Inagaki $H$, Sakakibara $O$, Miyaike $H$ et al : Mesenteric venous thrombosis in familial free protein S deficiency. Am J Gastroenterol 88 : 134-138, 1993

17) Porter J, Vesely M, Jane S et al : Mesenteric venous thrombosis with protein S deficiency. Am J Gastroenterol 88 : 2143, 1993

18）杉浦禎一, 新實紀二, 横井俊平ほか：プロテイン 
$\mathrm{S}$ 欠乏症による上腸間膜血栓症の 1 例. 日消外会 誌 31:2388一2391, 1998

19）矢島義昭, 宮里真一, 宮崎敦史ほか：上腸間膜静 脈よりウロキナーゼを投与して救命できたプロ テイン $\mathrm{S}$ 欠損症による門脈・上腸間膜静脈血栓 症の 1 例. 日消誌 $96: 1159-1164,1999$

20) Ludwig DJ, Hauptmann E, Rosoff L et al : Portal vein thrombosis in a young patient with protein $\mathrm{S}$ deficiency treated with urokinase via the superior mesenteric artery. J Vasc Surg 30 : 551554,1999

21) Draganov P, Lazarchick J, Portwood G : Mesenteric vein thrombosis secondary to protein $\mathrm{S}$ deficiency. Am J Gastroenterol 94 : 3616-3619, 1999

22) Tateishi A, Mitsui H, Oki T et al : Extensive mesenteric vein and portal vein thrombosis successfully treated by thrombolysis and anticoagulation. J Gastroenterol Hepatol 16 : 1429—1433, 2001

23）上村佳央, 小林研二, 小山太一ほか：上腸間膜静 脈門脈血栓症を発症したプロテイン $\mathrm{S}$ 欠乏症の 1 例. 日消外会誌 $35: 184-188,2002$

24）池田公正, 島野高志, 北田昌之ほか：プロテイン
S 欠乏症に起因した腸間膜静脈血栓症の 1 手術 例. 日消外会誌 $35: 332-336,2002$

25） Kato M, Iida S, Sato M et al : Superior mesenteric venous thrombosis associated with familial missense mutation (Pro626Ler) in the SHBG-like domain of the protein $\mathrm{S}$ molecule. Int $\mathrm{J}$ Hematol $75: 100-103,2002$

26）井上史彦, 松本賢治, 松原健太郎ほか：プロテイ ン $\mathrm{S}$ 欠乏症を伴う上腸間膜静脈血栓症の 1 例. 静 脈学 $15: 265$-270, 2004

27）森 康治, 勝又健次, 河北英明ほか：上腸間膜静 脈血栓症により腸管壊死をきたしたプロテイン S 欠乏症の 1 例. 日臨外会誌 $66: 1458-1472$, 2005

28) Engesser L, Broekmans AW, Briet E : Hereditary protein $\mathrm{S}$ deficiengy : clinical manifestations. Ann Intern Med 106 : 677-682, 1987

29) Wilson C, Walker ID, Davidson JF et al : Mesenteric venous thrombosis and antithrombin III deficiency. J Clin Pathol 40 : 906 - 908, 1987

30) Montany PF, Finley RK : Mesenteric venous thrombosis. Am Surg $55: 29-34,1988$

\title{
A Case of Mesenteric Vein Thrombosis Secondary to Protein S Deficiency
}

\author{
Yoshiko Yano and Hirofumi Hirai* \\ Department of Surgery, Chiba Prefecture Hospital of Sawara \\ Department of Surgery, Settu Iseikai Hospital*
}

\begin{abstract}
A 39-year-old man with abdominal pain was admitted to our hospital with a diagnosis of acute enteritis. None of the laboratory tests or imaging findings were abnormal except for marked leukocytosis of $13,100 \mathrm{cells} / \mathrm{mm}^{3}$. He was treated with antibiotics for few days, and the symptoms and laboratory findings improved. After oral feeding was resumed, the abdominal pain worsened and he developed signs of peritonitis. Contrast-enhanced CT scans on the 11th hospital day showed a large volume of ascitic fluid, thickened small bowel, and thrombi in the superior mesenteric vein. Laparotomy was performed for a preoperative diagnosis of acute peritonitis secondary to mesenteric vein thrombosis. Congestive necrosis of $25 \mathrm{~cm}$ of ileum and $35 \mathrm{~cm}$ of jejunum was observed intraoperatively, and they were resected to healthy margins. Intestinal continuity was restored by end-to-end anastomosis. Histopathological examination showed transmural hemorrhagic necrosis of the small bowel and thrombi in the superior mesenteric vein. Laboratory studies showed low levels of protein S activity (11\%) and protein S antigen (24.2\%). Because the patient had no underlying disease that might have caused the thrombosis, we concluded that this was a rare case of the mesenteric vein thrombosis associated with protein S deficiency.
\end{abstract}

Key words : protein S deficiency, mesenteric vein thrombosis

[Jpn J Gastroenterol Surg $39: 1611-1616,2006]$

Reprint requests : Yoshiko Yano Department of Surgery, Chiba Prefecture Hospital of Sawara 2285 Sawara, Sawara, 287-0003 JAPAN

Accepted : March 22, 2006 